\title{
SISTEM PAKAR DIAGNOSA KERUSAKAN LAPTOP BERBASIS WEBSITE DENGAN MENGGUNAKAN METODE DEMPSTER SHAFER
}

\author{
Agus Sehatman Saragih a,1,* ${ }^{\text {a }}$, Sherly Christina ${ }^{\text {b,2 }}$, Tiara Elshawina ${ }^{c, 3}$ \\ ${ }^{a}$ Universitas Palangka Raya, Jl. H. Timang \\ ${ }^{\mathrm{b}}$ Universitas Palangka Raya, Jl. H. Timang \\ ${ }^{\mathrm{c}}$ Universitas Palangka Raya, Jl. H. Timang \\ ${ }^{1}$ assaragih@ti.upr.ac.id *; -sherly.christina.upr@gmail.com ; ${ }^{3}$ elshawinatiara@gmail.com \\ * corresponding author
}

\section{ARTICLE INFO}

\section{Keywords}

Dempster Shafer

Forward Chaining

website

Expert System

Laptop damage

\begin{abstract}
Laptop is one type of computer that is much in demand by the public. Lay people at this time are still limited knowledge and sometimes have difficulty when faced with problems on laptops. So when you want to do first aid or solve problems do not know what to do. Technicians at the service center sometimes have a lot of problems when a lot has to be fixed with a variety of different obstacles. Laptop damage analysis is done manually and only done by technicians sometimes requires a lot of time with a limited number of technicians. The ability of a technician who can detect laptop damage can be implemented into an application system. However, this system can only detect laptop hardware damage. The methodology used in making this Expert System Website is a waterfall. System design using DFD (Data Flow Diagrams) and database design using ERD (Entity Relationship Diagrams), coding using PHP and MYSQL for databse and testing using blackboxes. On this Expert System uses Forward Chaining as reasoning and Dempster Shafer methods to calculate the trust results results. After testing, it can be seen the results of making this site that this website can carry out its function, namely diagnosing laptop hardware damage based on symptoms from visitors as laptop users who have answered questions.
\end{abstract}

\section{PENDAHULUAN}

Teknologi informasi dan komputer merupakan salah satu kebutuhan manusia yang paling mendasar terutama dalam membantu setiap pekerjaan dalam bidang komputerisasi. Dalam hal ini laptop merupakan salah satu jenis komputer yang banyak diminati oleh masyarakat.

Masyarakat awam pada saat ini masih terbatas pengetahuan dan terkadang mengalami kesulitan jika menghadapi masalah pada laptop atau mengidentifikasi letak kerusakan pada laptop. Sehingga pada saat mau melakukan pertolongan pertama atau menyelesaikan masalah, mereka tidak tahu apa yang harus dilakukan. Sangat dianjurkan bagi pengguna/user untuk mengetahui cara merawat dan memberikan pertolongan pertama ketika laptopnya bermasalah dan permasalahn tersebut yang masih dapat ditangani sendiri, sebelum memutuskan untuk menyerahkannya ke tempat servis.

Teknisi pada tempat servis terkadang banyak mengalami permasalahan ketika banyak yang harus dibenahi dengan berbagai kendala juga berbagai merk laptop yang berbeda-beda. Analisa kerusakan laptop yang dilakukan dengan cara manual dan hanya dikerjakan oleh teknisi terkadang membutuhkan waktu yang tidak sedikit dengan jumlah teknisi yang terbatas hal ini tentunya akan berbanding terbalik dengan jumlah pelanggan semakin banyak. 
Pada Aplikasi Sistem Pakar diagnosa kerusakan laptop ini menggunakan metode inferensi Forward Chaining dan Proses penarikan kesimpulan dari informasi/gejala yang di inputkan oleh user dalam sistem pakar dengan menggunakan metode Dempster Shafer.

Aplikasi sistem pakar bertujuan untuk fasilitas bagi pengguna laptop dalam mendiagnosa kerusakan pada laptop serta memberikan solusi, sehingga pengguna tahu tindakan yang dilakukan untuk penanggulangan secara dini dalam mengatasi masalah atau kerusakan laptop yang masih bisa di tangani sendiri dan fasilitas bagi teknisi servis laptop atau pakar dalam mendiagnosa kerusakan pada laptop serta memberikan solusi secara komputerisasi.

Sistem pakar ini akan dibangun berbasis website, sehingga dapat diakses hampir dimana saja dengan terhubungnya ke internet dan tanpa perlu melakukan penginstalan aplikasi sistem pakar terlebih dahulu.Sistem pakar ini melibatkan seorang ahli atau pakar yaitu teknisi yang berfungsi sebagai narasumber dalam perancangan sistem pakar mendiagnosa kerusakan laptop.

Teori yang digunakan pada penelitian ini adalah sebagai berikut.

\subsection{Sistem Pakar}

Sistem pakar adalah aplikasi berbasis komputer yang digunakan untuk menyelesaikan masalah sebagaimana yang dipikirkan oleh pakar. Pakar yang dimaksud adalah orang yang mempunyai keahlian khusus yang dapat menyelesaikan masalah yang tidak dapat diselesaikan oleh orang awam.

Sebuah sistem pakar memiliki 2 komponen utama yaitu basis pengetahuan dan mesin inferensi. Basis pengetahuan merupakan tempat penyimpanan pengetahuan dalam komputer, dimana pengetahuan ini diambil dari pengetahuan pakar. (Kusrini, 2008). Pada dasarnya sistem pakar diterapkan untuk mendukung aktifitas pemecahan masalah.

\subsection{Forward Chaining}

Forward Chaining adalah pelacakan ke depan yang memulai dari sekumpulan fakta-fakta dengan mencari kaidah yang cocok dengan dugaan/hipotesa yang ada untuk menuju kesimpulan. Forward chaining dimulai dengan data atau data driven. Artinya pada forward chaining semua data dan aturan akan ditelusuri untuk mencapai tujuan/goal yang diinginkan. Mesin inferensia yang menggunakan forward chaining akan mencari antesendent (IF klausa) sampai kondisinya benar. Pada forward chaining semua pertanyaan dalam sistem pakar akan disampaikan semuanya kepada pengguna.

Runut maju berarti menggunakan himpunan aturan kondisi-aksi. Dalam metode ini, data digunakan untuk menetukan aturan mana yang akan dijalankan, kemudian aturan tersebut dijalankan. Mungkin proses menambah data ke memori kerja. Proses diulang sampai ditemukan suatu hasil.

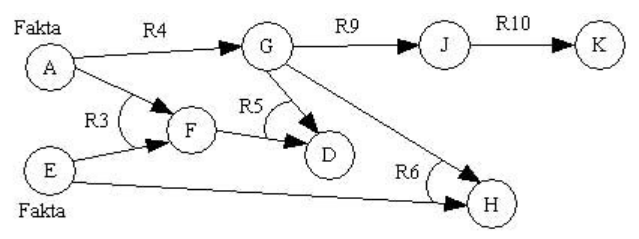

Gambar 1. Contoh Forward Chaining 


\subsection{Dempster Shafer}

Dempster Shafer adalah suatu teori matematika untuk pembuktian berdasarkan belief functions (fungsi kepercayaan) dan plausible reasoning (pemikiran yang masuk akal), yang digunakan untuk mengkombinasikan potongan informasi yang terpisah (bukti) untuk mengkalkulasi kemungkinan dari suatu peristiwa. Secara umum Teori Dempster-Shafer ditulis dalam suatu interval:

\section{[Belief,Plausibility]}

Belief (Bel) adalah ukuran kekuatan evidence dalam mendukung suatu himpunan proposisi.Jika bernilai 0 maka mengindikasikan bahwa tidak ada evidence, dan jika bernilai 1menunjukkan adanya kepastian.Plausibility (Pl) akan mengurangi tingkat kepastian dari evidence. Plausibility $(\mathrm{Pl})$ dinotasikan sebagai:

$$
P l(s)=1-\operatorname{Bel}(\neg s)
$$

Plausibility juga bernilai 0 sampai 1 . Jika kita yakin akan $X^{\prime}$, maka dapat dikatakan bahwa $\operatorname{Bel}\left(\mathrm{X}^{\prime}\right)=1$, dan $\mathrm{Pl}(\neg \mathrm{s})=0$. Pada teori Dempster-Shafer kita mengenal adanya frame ofdiscernment yang inotasikan dengan $\theta$. Frame ini merupakan semesta pembicaraan dariekumpulan hipotesis.

Tujuan kita adalah mengkaitkan ukuran kepercayaan elemen-elemen $\theta$. Tidak semuaevidence secara langsung mendukung tiap-tiap elemen.(Sri Kusumadewi, 2003)

Keterangan :

$$
\mathrm{m} 3(\mathrm{Z})=\frac{\sum_{X \cap Y=Z} m_{1}(X) \cdot m_{2}(Y)}{1-\sum_{X \cap Y=\varnothing} m_{1}(X) \cdot m_{2}(Y)}
$$

$\mathrm{m}_{3}(\mathrm{Z})=$ nilai densitasdari kombinasi

gejala $(\mathrm{X})$ dan gejala $(\mathrm{Y})$

$\mathrm{m}_{1}(\mathrm{X})=$ nilai densitasdari gejala $(\mathrm{X})$

$\mathrm{m} 2(\mathrm{Y})=$ nilai densitasdari gejala $(\mathrm{Y})$

\section{Metode Penelitian}

Metode penelitian yang digunakan pada penelitian ini adalah sebagai berikut.

2.1 Metode Pengembangan Perangkat Lunak

Menurut Ian Sommerville (2011, p30-31), tahapan utama dari waterfall model langsung mencerminkan aktivitas pengembangan dasar. Terdapat 5 tahapan pada waterfall model, yaitu

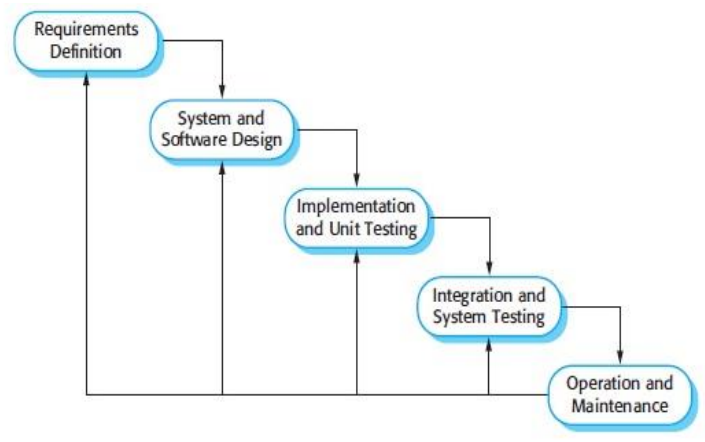

Gambar 2Waterfall Model

(Sumber : Ian Sommerville, 2011, 30)

a. Requitments Definition (Definisi Kebutuhan)

Langkah ini merupakan analisa terhadap kebutuhan yang diperlukan dalam pembuatanuntuk mendapatkan pilihan dan solusi fitur apa yang akan dirancaing. Sehingga 
kebutuhan tersebut yang akan menjadi acuan sistem analisis untuk menterjemahkan kedalam bahasa pemrograman, di mana menetapkan fitur-fitur, kendala dan tujuan sistem.

b. System dan Software Design (Desain Sistem dan Software)

Pada tahap ini dilakukan desain aplikasi yang meliputi desain interface atau tampilan website dengan menterjemahkan sesuai dengan syarat/kebutuhan ke dalam sebuah representasi aplikasi yang dapat diperkirakan demi kualitas sebelum dimulai pengkodean.

c. Implementation and Unit Testing (Implementasi dan pengujian unit)

Tahapan inilah merupakan mengerjakan suatu sistem. Dimana desain sistem dan desain interface aplikasi yang dirancang sebelumnya di implementasikan dengan melakukan pembangunan aplikasi yang diterjemahkan ke kode-kode dalam satu set program atau unit program. Setelah pengkodean selesai maka akan dilakukan testing terhadap sistem yang telah dibuat tadi secara unit. Tujuan testing untuk menemukan kesalahan - kesalahan terhadap sistem tersebut dan kemudian bisa diperbaiki.

d. Integration and System Testing (Integrasi dan Pengujian Sistem)

Dalam tahapan ini, setiap unit program akan diintegrasikan satu sama lain atau menyatukan semua unit program untuk diuji secara keseluruhan untuk mendeteksi apakah ada bug atau error didalam website ini agar terjamin bahwa persyaratan sistem telah dipenuhi atau sudah memenuhi spesifikasi aplikasinya. Setelah pengujian sistem, perangkat lunak dikirim ke pengguna.

e. Operation and Maintenance (Operasi dan Pemeliharaan)

Pada tahapan ini sistem diinstal atau mulai digunakan. Melakukan juga pemeliharaan yang mencakup koreksi dan berbagai kesalahan yang tidak ditemukan pada tahap-tahap sebelumnya, perbaikan atas implementasi unit sistem dan pengembangan sistem sebagai penemuan kebutuhan baru, penambahan fitur dan fungsi baru.

\section{Hasil Dan Pembahasan}

Hasil penelitian dan pembahasan pada penelitian ini adalah analisis dan desain dan impelmentasinaya.

\subsection{Diagram Konteks}

Diagram konteks berikut digunakan untuk menggambarkan proses sistem. Diagram konteks ini dirancang memperhatikan masukan yang dibutuhkan oleh sistem dan keluaran yang dihasilkan oleh sistem. Diagram Konteks disebut juga dengan DFD Level 0 keseluruhan.

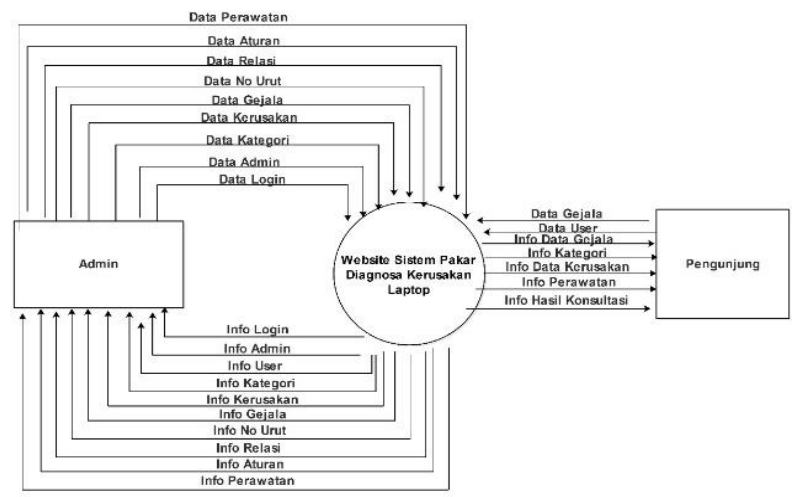

Gambar 2 Diagaram Konteks

Pada gambar di atas terdapat Diagram Konteks, dimana dalam diagram ini terdapat dua pihak terkait yang digambarkan secara umum. Kesatuan luar yang terlibat secara langsung adalah Admin dan Pengunjung. Admin berfungsi sebagai pengelola Website Sistem Pakar 


\section{JURNAL TEKNOLOGI INFORMASI}

[E-ISSN 2656-0321]

[Vol. 12 No. 2]

Jurnal Keilmutan dan Aplikasi Bidang Tekník Iniormatilka

[Agustus 2018]

Kerusakan Laptop, Pengunjung sebagai pihak yang mengakses Website Sistem Pakar Kerusakan Laptop dan melakukan konsultasi permasalahan pada laptop.

\subsection{Data Flow Diagram}

Proses pada DFD memberikan gambaran umum proses-proses dalam website beserta input dan output. Pada level ini terdapat 10 proses, yaitu:

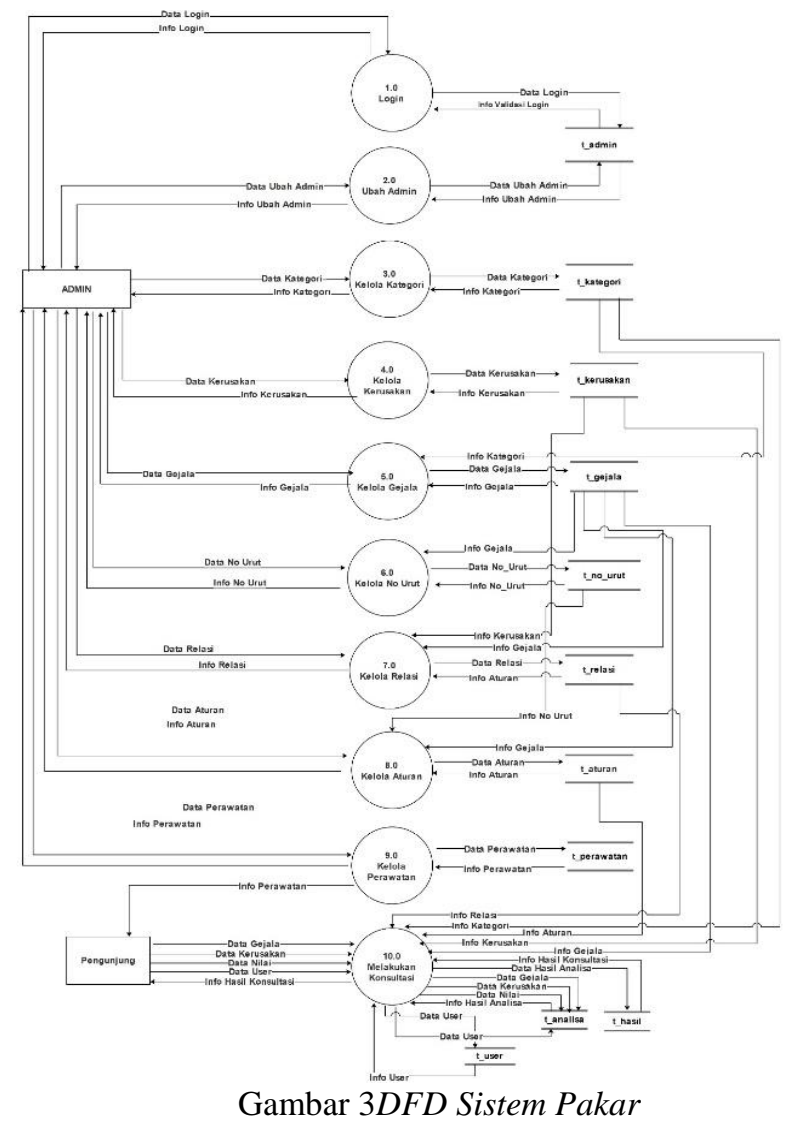

a. Proses $1.0:$ Login

Dalam proses ini admin melakukan login dengan menginputkan username dan password setelah itu cek validasi dari tabel admin sehingga admin dapat menerima info berhasil login dan masuk ke halaman web.

b. Proses 2.0: Ubah Admin

Dalam proses ini admin mengibah password dan username lalu disimpan ke dalam tabel admin dan ditampilkan ke sistem sehingga admin dapat menerima info username dan password admin.

c. Proses 3.0 : Kelola Kategori

Dalam proses ini admin mengelola kategori diinputkan dan disimpan ke dalam tabel kategori dan ditampilkan ke sistem sehingga admindapat menerima info kategorike sistem sehingga admindapat menerima info gejala

d. Proses 4.0 : Kelola Kerusakan

Dalam proses ini admin mengelola kerusakan diinputkan dan disimpan ke dalam tabel kerusakan dan ditampilkan ke sistem sehingga admindapat menerima info kerusakan 
e. Proses 5.0 : Kelola Gejala

Dalam proses ini admin mengelola gejala diinputkan dan disimpan ke dalam tabel gejala dan ditampilkan

f. Proses 6.0 : Kelola No Urut

Dalam proses ini admin mengelola nomor urut kode gejala diinputkan dan disimpan ke dalam tabel no urut dan ditampilkan

g. Proses 8.0 : Kelola Relasi

Dalam proses ini admin mengelola relasi diinputkan dan disimpan ke dalam tabel relasi dan ditampilkan ke sistem sehingga admindapat menerima info relasi

h. Proses 7.0 : Kelola Aturan

Dalam proses ini admin mengelola aturan diinputkan dan disimpan ke dalam tabel aturan dan ditampilkan

i. Proses 9.0 : Kelola Perawatan

Dalam proses ini admin mengelola data perawatan laptop yang diinputkan dan disimpan ke dalam tabel perawatan dan ditampilkan ke sistem sehingga admin menerima info perawatan, pengunjung dapat menerima info data pegawai

j. Proses 10.0 :Melakukan KonsultasiDalam proses ini pengunjung melakukan konsultasi dengan menginputkan nama dan jenis kelamin ke sistem yang di simpan ke dalam tabel user selanjutnya mengiputkan gejala-gejala ke sistem yang disimpan ke dalam tabel hasil dan ditampilkan ke sistem sehingga pengunjung dapat menerima info hasil konsultasi.

\subsection{Entity Relationship Diagram}

Entity-Relationship Diagram (ERD) adalah suatu pemodelan dari basis data relasional yang didasarkan atas persepsi di dalam dunia nyata, dunia ini senantiasa terdiri dari sekumpulan objek yang saling berhubungan antara satu dengan yang lainnya. Suatu objek disebut entity dan hubungan yang dimilikinya disebut relationship. Suatu entity bersifat unik dan memiliki atribut sebagai pembeda dengan entity lainnya. Berikut gambarERD dari sistem ini :

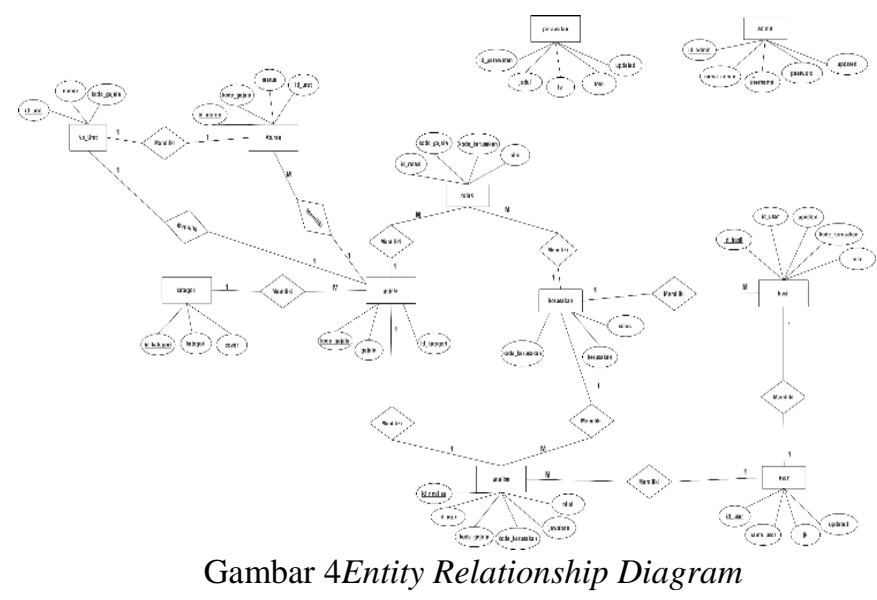

\subsection{Perancangan Data}

Data yang dibutuhkan dalam basis pengetahuan sistem pakar diagnosis kerusakan laptop adalah data gejala, data kerusakan, nilai belief dari setiap gejala, dan aturan untuk menarik kesimpulan. 
Tabel 1Kerusakan Laptop

\begin{tabular}{cl}
\hline $\begin{array}{c}\text { Kode } \\
\text { Penyakit }\end{array}$ & \multicolumn{1}{c}{ Nama Penyakit } \\
\hline K1 & Kerusakan pada IC VGA \\
\hline K2 & Kerusakan pada IC Power \\
\hline K3 & $\begin{array}{l}\text { Kerusakan Inventer/gangguan pada } \\
\text { kabel fleksibel laptop }\end{array}$ \\
\hline K4 & Kerusakan pada LCD \\
\hline K5 & Kerusakan Pada Keyboard Laptop \\
\hline K6 & Kerusakan Pada TouchPad Laptop \\
\hline K7 & Kerusakan pada Harddisk laptop \\
K8 & Kerusakan pada Charger Laptop \\
\hline K9 & Kerusakan pada Sound Card \\
\hline K10 & Kerusakan pada RAM \\
K11 & Kerusakan pada Baterai CMOS \\
\hline K12 & Kerusakan pada Baterai Laptop \\
\hline K13 & Kerusakan pada Wireless Card \\
\hline K14 & Kerusakan Port USB laptop \\
\hline K15 & Kerusakan pemutar CD/DVD \\
\hline
\end{tabular}

Tabel 2Gejala-Nilai Belief Kerusakan Laptop

\begin{tabular}{|c|c|c|}
\hline $\begin{array}{c}\text { Kode } \\
\text { Penyakit }\end{array}$ & Nama Penyakit & $\begin{array}{l}\text { Nilai } \\
\text { Belief }\end{array}$ \\
\hline G1 & $\begin{array}{l}\text { Suhu Laptop meningkat secara drastis } \\
\text { saat pertama kali di hidupkan }\end{array}$ & 0,6 \\
\hline G2 & $\begin{array}{l}\text { Ukuran resolusi layar mengecil atau } \\
\text { teks dan icon pada layar laptop } \\
\text { membesar }\end{array}$ & 0,5 \\
\hline G3 & $\begin{array}{l}\text { Indikator lampu LED Power pada } \\
\text { laptop nyala ketika laptop di hidupkan } \\
\text { tetapi gambar tidak muncul }\end{array}$ & 0,7 \\
\hline G4 & $\begin{array}{l}\text { Indikator lampu LED Power pada } \\
\text { laptop tidak nyala ketika laptop di } \\
\text { hidupkan }\end{array}$ & 0,7 \\
\hline G5 & $\begin{array}{l}\text { Laptop tidak menampilkan gambar } \\
\text { dilayar/ gelap }\end{array}$ & 0,6 \\
\hline G6 & $\begin{array}{l}\text { Cahaya pada layar laptop redup gelap } \\
\text { namun menampilkan gambar }\end{array}$ & 0,8 \\
\hline G7 & $\begin{array}{l}\text { Layar kadang hidup mati dalam } \\
\text { menampilkan gambar }\end{array}$ & 0,5 \\
\hline G8 & $\begin{array}{l}\text { Gambar yang ditampilkan bergetar / } \\
\text { abnormal }\end{array}$ & 0,6 \\
\hline G9 & $\begin{array}{l}\text { Terdapat garis-garis pada layar/LCD } \\
\text { laptop }\end{array}$ & 0,8 \\
\hline G10 & $\begin{array}{l}\text { Terdapat titik-titik pada beberapa area } \\
\text { layar/LCD laptop bagian lainya } \\
\text { memiliki area terang }\end{array}$ & 0,5 \\
\hline
\end{tabular}


G11

Ketika laptop sedang jalan, tampilan $\quad 0,6$ tiba-tiba hilang dan layar jadi gelap

\begin{tabular}{clc} 
& tiba-tiba hilang dan layar jadi gelap & \\
\hline G12 & $\begin{array}{l}\text { Ketika dihubungkan ke LCD external } \\
\text { melalui Port VGA Card bisa } \\
\text { menampilkan gambar di layar LCD }\end{array}$ & 0,4 \\
\hline G13 & $\begin{array}{l}\text { Ada sebagian/semua tombol keyboard } \\
\text { yang tidak berfungsi }\end{array}$ & 0,7 \\
\hline G14 & $\begin{array}{l}\text { Ketika laptop dinyalakan bunyi bip } \\
\text { yang panjang dan terus menerus pada } \\
\text { laptop }\end{array}$ & 0,6 \\
\hline \multirow{6}{*}{ K15 } & $\begin{array}{l}\text { Keyboard error tiba-tiba mengetikkan } \\
\text { huruf yang tidak sesuai dengan yang }\end{array}$ & 0,5
\end{tabular}

G15 kita inginkan atau random / terketik sendiri

\begin{tabular}{lll} 
G16 & $\begin{array}{l}\text { Kursor pada laptop yang melompat- } \\
\text { lompat sendiri }\end{array}$ & 0,6 \\
\hline
\end{tabular}

\begin{tabular}{|c|c|c|}
\hline G17 & Kursor bergerak sendiri & 0,8 \\
\hline G18 & Sensitifitas mouse/touchpad melambat & 0,4 \\
\hline G19 & $\begin{array}{l}\text { Touchpad pada laptop tidak } \\
\text { berfungsi/kursor tidak mau bergerak }\end{array}$ & 0,7 \\
\hline $\mathrm{G} 20$ & $\begin{array}{l}\text { Ketika Klik kanan/kiri pada touchpad } \\
\text { tidak berfungsi/kursor hanya diam }\end{array}$ & 0,5 \\
\hline $\mathrm{G} 21$ & Instalasi OS pada hardisk selalu gagal & 0,6 \\
\hline $\mathrm{G} 22$ & Hardisk tidak terbaca di boot menu & 0,8 \\
\hline G23 & $\begin{array}{l}\text { Menampilkan pesan check hardisk di } \\
\text { layar }\end{array}$ & 0,5 \\
\hline $\mathrm{G} 24$ & Laptop tidak mau masuk ke OS & 0,7 \\
\hline G25 & Laptop lemot/lambat & 0,4 \\
\hline G26 & $\begin{array}{l}\text { Terdengar suara crash saat hardisk } \\
\text { bekerja }\end{array}$ & 0,9 \\
\hline G27 & $\begin{array}{l}\text { Indikasi lampu yang terhubung pada } \\
\text { charger pada laptop tidak hidup }\end{array}$ & 0,7 \\
\hline $\mathrm{G} 28$ & $\begin{array}{l}\text { Ketika Charger dihubungkan ke laptop } \\
\text { namun charger tidak mau mengisi daya } \\
\text { ke laptop }\end{array}$ & 0,6 \\
\hline G29 & $\begin{array}{l}\text { Ketika Charger dihubungkan ke laptop, } \\
\text { laptop tiba-tiba mati }\end{array}$ & 0,8 \\
\hline G30 & $\begin{array}{l}\text { Ketika Charger dihubungkan ke laptop } \\
\text { namun daya yang terisi lambat mengisi } \\
\text { baterai }\end{array}$ & 0,5 \\
\hline G31 & Laptop tidak mengeluarkan suara & 0,8 \\
\hline G32 & Pengaturan volume tidak berfungsi & 0,6 \\
\hline G33 & $\begin{array}{l}\text { Muncul notifikasi X pada icon speaker } \\
\text { di taskbar }\end{array}$ & 0,7 \\
\hline G34 & $\begin{array}{l}\text { Lampu indikator power dan fan/kipas } \\
\text { hidupdilayar }\end{array}$ & 0,7 \\
\hline G35 & Laptop Blue Screen atau restart sendiri & 0,6 \\
\hline G36 & $\begin{array}{l}\text { Tidak bisa menyimpan pengaturan } \\
\text { BIOS }\end{array}$ & 0,8 \\
\hline G37 & $\begin{array}{l}\text { Pengaturan tanggal dan waktu selalu } \\
\text { kembali di tanggal yang sama ketika OS } \\
\text { di jalankan }\end{array}$ & 0,7 \\
\hline G38 & $\begin{array}{l}\text { Muncul notifikasi baterai CMOS Error } \\
\text { di BIOS }\end{array}$ & 0,6 \\
\hline
\end{tabular}




\begin{tabular}{|c|c|c|}
\hline G39 & $\begin{array}{l}\text { Baterai tidak bisa terisi penuh walaupun } \\
\text { charger sudah dihubungkan ke laptop }\end{array}$ & 0,8 \\
\hline G40 & $\begin{array}{l}\text { Baterai cepat penuh setelah di charger } \\
\text { namun setelah charger dilepas dari } \\
\text { laptop baterai cepat kosong atau laptop } \\
\text { segera mati }\end{array}$ & 0,7 \\
\hline G41 & $\begin{array}{l}\text { Baterai tidak terdeteksi di laptop } \\
\text { walaupun baterai terpasang pada laptop }\end{array}$ & 0,5 \\
\hline G42 & $\begin{array}{l}\text { Laptop hidup ketika charger terhubung } \\
\text { dengan laptop setelah dilepas laptop } \\
\text { langsung mati atau Baterai tidak bisa } \\
\text { menyimpan daya }\end{array}$ & 0,6 \\
\hline G43 & $\begin{array}{l}\text { Muncul notifikasi consider replacement } \\
\text { baterai atau tanda X pada icon batrei di } \\
\text { taskbar }\end{array}$ & 0,7 \\
\hline G44 & $\begin{array}{l}\text { Laptop tidak bisa dapat mendeteksi } \\
\text { sinyal WiFi }\end{array}$ & 0,8 \\
\hline G45 & Icon wireless ada tanda seru kuning & 0,6 \\
\hline G46 & Icon wireless ada tanda $X$ & 0,7 \\
\hline G47 & $\begin{array}{l}\text { Perangkat eksternal terhubung ke Port } \\
\text { USB pada laptop namun tidak bisa } \\
\text { bekerja }\end{array}$ & 0,8 \\
\hline G48 & $\begin{array}{l}\text { Muncul notifikasi "USB Not } \\
\text { Recognized" }\end{array}$ & 0,7 \\
\hline G49 & $\begin{array}{l}\text { Laptop tidak bisa membaca CD maupun } \\
\text { DVD }\end{array}$ & 0,8 \\
\hline G50 & $\begin{array}{l}\text { Drive DVD tidak muncul di My } \\
\text { Computer }\end{array}$ & 0,7 \\
\hline G51 & $\begin{array}{l}\text { Pemutar CD/DVD lambat membaca } \\
\text { data }\end{array}$ & 0,5 \\
\hline G52 & $\begin{array}{l}\text { Pemutar CD/DVD tidak bisa } \\
\text { keluar/masuk }\end{array}$ & 0,6 \\
\hline
\end{tabular}

Aturan penalaran yang digunakan adalah Rule-Based Reasoning (penalaran berbasis aturan). Berikut ini adalah aturannya :

\section{Rule 1}

If Suhu Laptop meningkat secara drastis saat pertama kali di hidupkan

And Ukuran resolusi layar mengecil atau teks dan icon pada layar laptop membesar And Indikator lampu LED Power pada laptop nyala ketika laptop di hidupkan tetapi gambar tidak muncul Then Kerusakan pada IC VGA

\section{Rule 2}

If Suhu Laptop meningkat secara drastis saat pertama kali di hidupkan And Indikator lampu LED Power pada laptop tidak nyala ketika laptop di hidupkan Then Kerusakan pada IC Power

\section{Rule 3}

If LCD tidak menampilkan gambar /gelap And Cahayapada layar laptop redup gelap namun menampilkan gambarAnd Layar kadang hidup mati dalam menampilkan gambar And Gambar yang ditampilkan bergetar / abnormal Then Kerusakan inventer/gangguan pada kabel fleksibel laptop

\section{Rule 4}

If Laptop tidak menampilkan gambar dilayar AndTerdapat garis-garis pada layar/LCD laptop And Terdapat titik-titik pada beberapa area layar/LCD laptop bagian lainya memiliki 
area terang And Ketika laptop sedang jalan, tampilan tiba-tiba hilang dan layar jadi gelap.And Ketika dihubungkan ke LCD external melalui Port VGA Card bisa menampilkan gambar di layar LCD Then Kerusakan pada LCD

\section{Rule 5}

If Ada sebagian/semua tombol keyboard yang tidak berfungsi And Ketika laptop dinyalakan bunyi bip yang panjang dan terus menerus pada laptop And Keyboard error tibatiba mengetikkan huruf yang tidak sesuai dengan yang kita inginkan atau random / terketik sendiri Then Kerusakan pada Keyboard Laptop

\section{Rule 6}

If Kursor pada laptop yang melompat-lompat sendiri And Kursor bergerak sendiri And Sensitifitas mouse/touchpad melambat And Touchpad pada laptop tidak berfungsi/kursor tidak mau bergerak And Ketika Klik kanan/kiri pada touchpad tidak berfungsi/kursor hanya diam Then Kerusakan pada Touchpad laptop

\section{Rule 7}

If Instalasi OS pada hardisk selalu gagal And Hardisk tidak terbaca di boot menu And Menampilkan pesan check hardisk di layar And Laptop tidak mau masuk ke OS And Laptop lemot/lambat And Terdengar suara crash saat hardisk bekerja Then Kerusakan pada Harddisk laptop

\section{Rule 8}

If Indikasi lampu yang terhubung pada charger pada laptop tidak hidup AndKetika Charger dihubungkan ke laptop namun charger tidak mau mengisi daya ke laptop And Ketika Charger dihubungkan ke laptop, laptop tiba-tiba mati And Ketika Charger dihubungkan ke laptop namun daya yang terisilambat mengisi bateraiThen Kerusakan pada Charger laptop

\section{Rule 9}

If Laptop tidak mengeluarkan suara And Pengaturan volume tidak berfungsi And Muncul notifikasi X pada icon speaker di taskbar Then Kerusakan pada Sound Card

Rule 10

If Laptop tidak menampilkan gambar dilayar/ gelap And Lampu indikator power dan fan/kipas hidupdilayar And Laptop Blue Screen atau restart sendiri

Then Kerusakan pada RAM

\section{Rule 11}

If Tidak bisa menyimpan pengaturan BIOS And Pengaturan tanggal dan waktu selalu kembali di tanggal yang sama ketika OS di jalankan And Muncul notifikasi baterai CMOS Error di BIOS Then Kerusakan pada Baterai CMOS

\section{Rule 12}

If Baterai tidak bisa terisi penuh walaupun charger sudah dihubungkan ke laptop And Baterai cepat penuh setelah di charger namun setelah charger dilepas dari laptopbaterai cepat kosong atau laptop segera mati And Baterai tidak terdeteksi di laptop walaupun baterai terpasang pada laptop And Laptop hidup ketika charger terhubung dengan laptop setelah dilepas laptop langsung mati atau Baterai tidak bisa menyimpan daya And Muncul notifikasi consider replacement baterai atau tanda $\mathrm{X}$ pada icon batrei di taskbar Then Kerusakan pada Baterai Laptop

\section{Rule 13}

If Laptop tidak bisa dapat mendeteksi sinyal WiFi And Icon wireless ada tanda seru kuning And Icon wireless ada tanda X Then Kerusakan pada Wireless Card

\section{Rule 14}


If Perangkat eksternal terhubung ke Port USB pada laptop namun tidak bisa bekerja And Muncul notifikasi "USB Not Recognized" Then Kerusakan Port USB laptop

Rule 15

If Laptop tidak bisa membaca CD maupun DVD And Drive DVD tidak muncul di My Computer And Pemutar CD/DVD lambat membaca dataAnd Pemutar CD/DVD tidak bisa keluar/masuk Then Kerusakan pemutar CD/DVD

\subsection{Perhitungan Metode Dempster Shafer Pada Kerusakan Laptop}

\section{Kasus Dengan 3 Gejala}

Misalkan gejala yang diinputkan oleh user pada sistem pakar kerusakan laptop:

Gejala 1 : Suhu Laptop meningkat secara drastis saat pertama kali di hidupkan

Gejala 2 : Ukuran resolusi layar mengecil atau teks dan icon pada layar laptop membesarr

Gejala 3 : Indikator lampu LED Power pada laptop nyala ketika laptop di hidupkan tetapi gambar tidak muncul

Bedasarkan tabel daftar gejala, Gejala 1 : Suhu Laptop meningkat secara drastis saat pertama kali di hidupkan, merupakan gejala dari kerusakan laptop dengan nilai desintas $\mathrm{m}\{\mathrm{K} 1\}=0.6, \mathrm{~m}\{\mathrm{~K} 2\}=0.6$, maka :

$$
\begin{gathered}
\mathrm{m} 1\{\mathrm{~K} 1, \mathrm{~K} 2\}=0.6 \\
P l(s)=1-\operatorname{Bel}(\neg s) \\
\mathrm{m} 1\{\theta\}=1-0.6=0.4
\end{gathered}
$$

Bedasarkan tabel daftar gejala, Gejala 2 : Ukuran resolusi layar mengecil atau teks dan icon pada layar laptop membesarr, merupakan kerusakan dari laptop dengan nilai desintas $\mathrm{m} 2\{\mathrm{~K} 1\}=0.5$, maka :

$$
\begin{aligned}
& \mathrm{m} 2\{\mathrm{~K} 1\}=0.5 \\
& P l(s)=1-\operatorname{Bel}(\neg s) \\
& \mathrm{m} 2\{\theta\}=1-0.5=0.5
\end{aligned}
$$

Maka selanjutnya dihitung nilai densitas (m) baru yaitu $\mathrm{m} 3$ dengan membuat tabel aturan kombinasi terlebih dahulu.

\begin{tabular}{ccc}
\multicolumn{3}{c}{ Aturan Kombinasi Untuk m3 } \\
\cline { 2 - 3 } $\mathrm{m} 1$ & \multicolumn{2}{c}{$\mathrm{m} 2$} \\
& $\{\mathrm{~K} 1\}=0.5$ & $\{\theta\}=0.5$ \\
& & \\
$\{\mathrm{~K} 1, \mathrm{~K} 2\}=0.6$, & $\{\mathrm{~K} 1\}=0.3$ & $\{\mathrm{~K} 1, \mathrm{~K} 2\}=0.3$ \\
\hline$\{\theta\}=0.4$ & $\{\mathrm{~K} 1\}=0.2$ & $\{\theta\}=0.2$ \\
\hline
\end{tabular}

$\mathrm{m} 3\{\mathrm{~K} 1\}=\frac{0.3+0.22}{1-0}=0.5$

$\mathrm{m} 3\{\mathrm{~K} 1, \mathrm{~K} 2\}=\frac{0.3}{1-0}=0.3$

$\mathrm{m} 3\{\theta\}=\frac{0.2}{1-0}=0.2$

Berdasarkan gejala-gejala yang telah dihitung untuk kerusakan laptop dengan metode Dempster-Shafer, nilai densitas yang paling tinggi adalahm $3\{\mathrm{~K} 1\}$ yaitu sebesar 0.5 . 
Bedasarkan tabel daftar gejala, Gejala 3 : Indikator lampu LED Power pada laptop nyala ketika laptop di hidupkan tetapi gambar tidak muncul dengan nilai desintas $\mathrm{m} 4\{\mathrm{~K} 1\}=0.7$, maka

$$
\begin{aligned}
& \mathrm{m} 4\{\mathrm{~K} 1\}=0.7 \\
& P l(s)=1-\operatorname{Bel}(\neg s) \\
& \mathrm{m} 4\{\theta\}=1-0.7=0.3
\end{aligned}
$$

Maka selanjutnya dihitung nilai densitas (m) baru yaitu m5 dengan membuat tabel aturan kombinasi terlebih dahulu

\begin{tabular}{lll}
\multicolumn{3}{c}{ Aturan Kombinasi Untuk m5 } \\
\cline { 2 - 3 } $\mathrm{m} 3$ & \multicolumn{2}{c}{$\mathrm{m} 4$} \\
& & \\
& $\{\mathrm{~K} 1\}=0.7$ & $\{\theta\}=0.3$ \\
& & \\
\hline$\{\mathrm{K} 1\}=0.5$ & $\{\mathrm{~K} 1\}=0.35$ & $\{\mathrm{~K} 1\}=0.15$ \\
\hline$\{\mathrm{K} 1, \mathrm{~K} 2\}=0.3$ & $\{\mathrm{~K} 1\}=0.21$ & $\{\mathrm{~K} 1, \mathrm{~K} 2\}=$ \\
& & 0.09 \\
\hline$\{\theta\}=0.2$ & $\{\mathrm{~K} 1\}=0.14$ & $\{\theta\}=0.06$ \\
\hline & &
\end{tabular}

Sehingga didapat perhitungan :

$$
\begin{aligned}
& \operatorname{m} 5\{K 4\}=\frac{0.35+0.21+0.14+0.15}{1-0}=0.85 \\
& \operatorname{m} 5\{K 1, K 2\}=\frac{0.09}{1-0}=0.09 \\
& \operatorname{m} 5\{\theta\}=\frac{0.06}{1-0}=0.06
\end{aligned}
$$

Berdasarkan gejala-gejala yang telah dihitung untuk kerusakan laptop dengan metode Dempster-Shafer, nilai densitas yang paling tinggi adalahm5 $\{\mathrm{K} 1\}$ yaitu sebesar 0.87 , sehingga dapat disimpulkan bahwa kerusakan pada laptop kemunggkinan adalah kerusakan pada IC VGA.

\subsection{Implementasi}

a. Halaman Admin

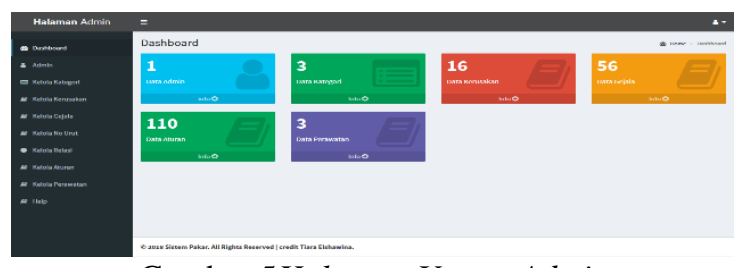

Gambar 5Halaman Utama Admin

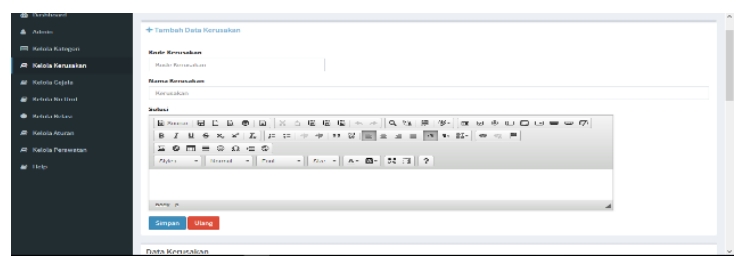

Gambar 6Halaman Kelola Kerusakan 

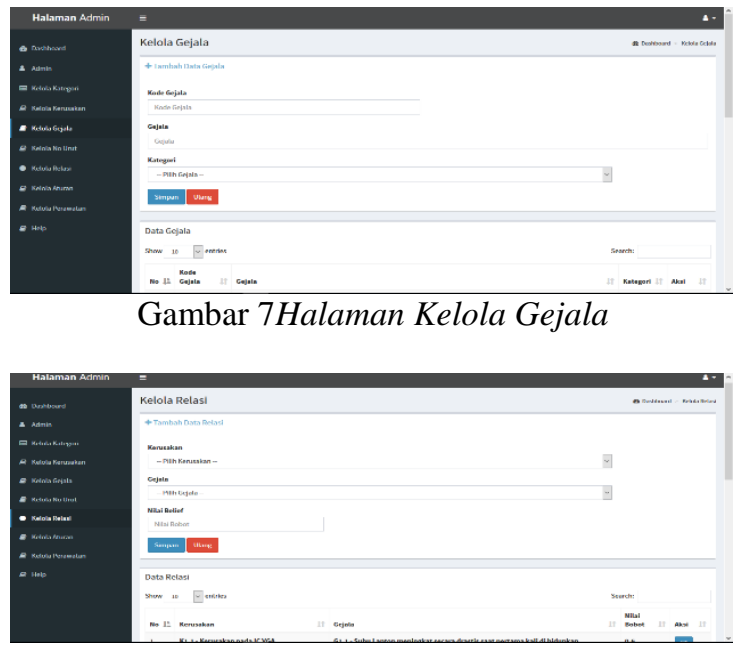

Gambar 8Halaman Kelola Relasi

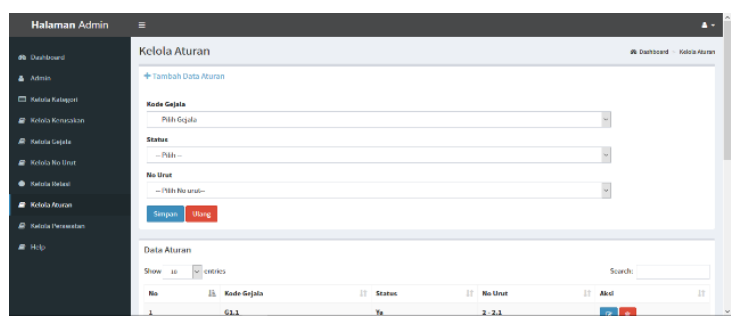

Gambar 9Halaman Kelola Aturan

b. Halaman Pengunjung

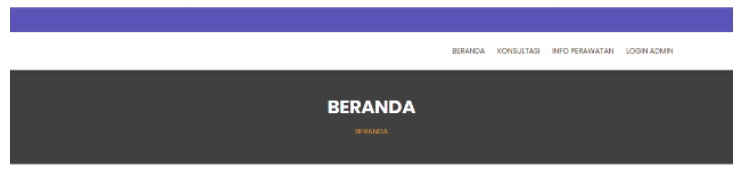

SELAMAT DATANG DI WEBSITE SISTEM PAKAR

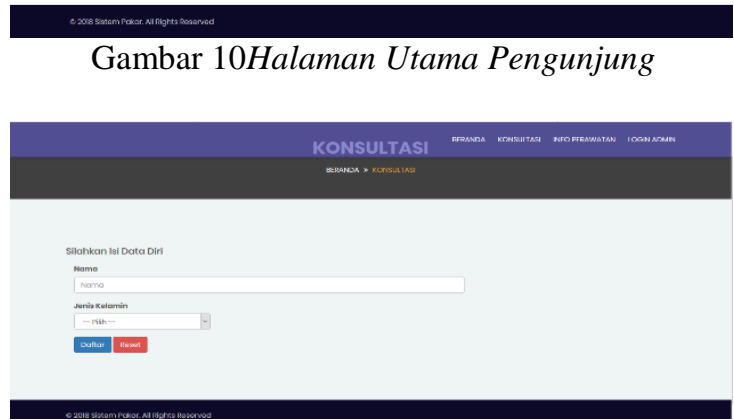

Gambar 11Halaman Isi Data Konsultasi 


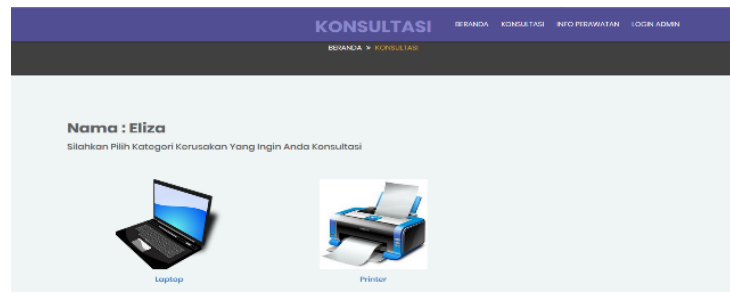

Gambar 12Halaman Pilih Kategori

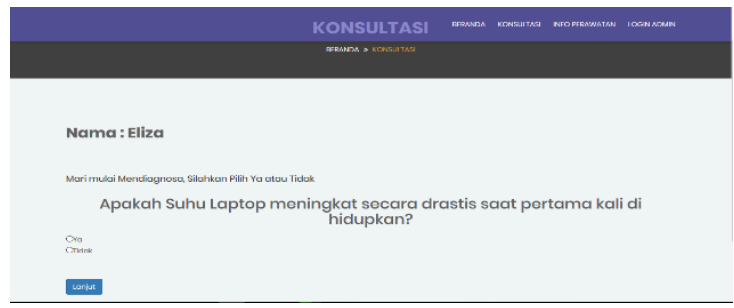

Gambar 13Halaman Pertanyaan Kosultasi

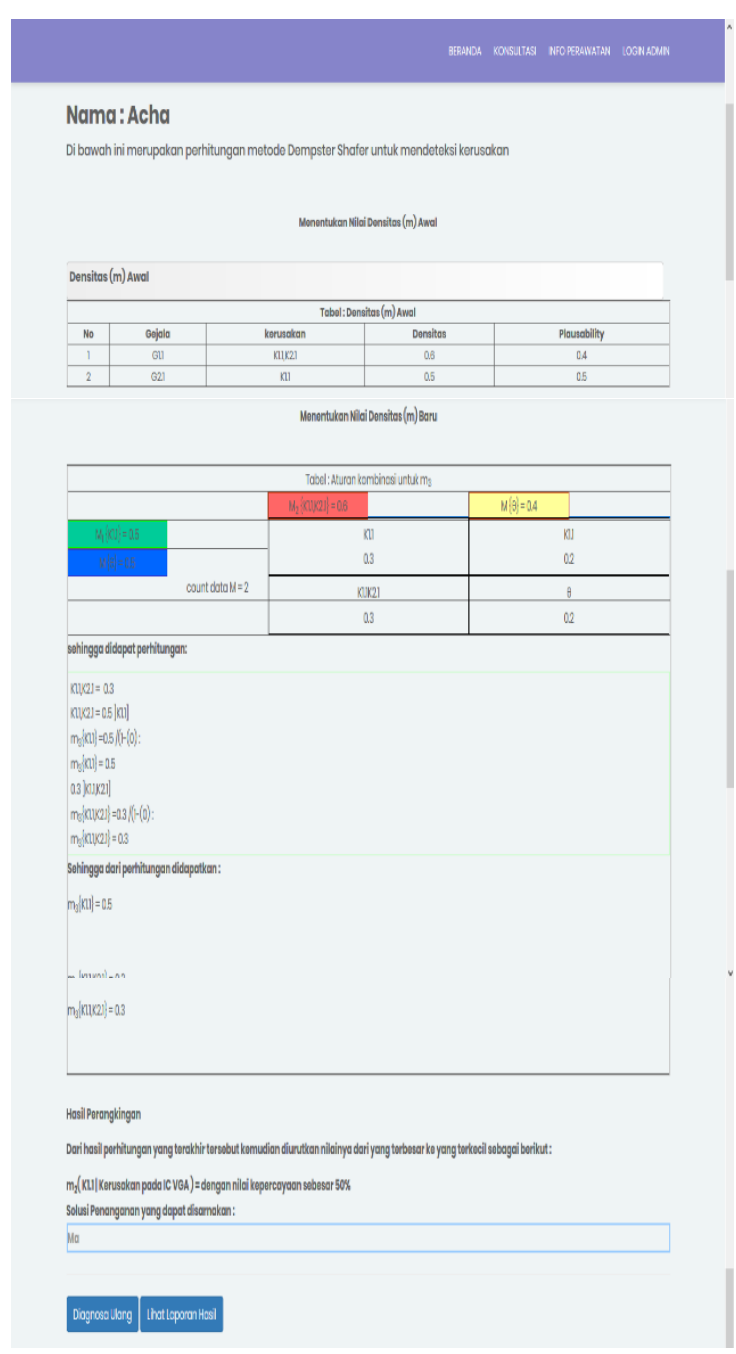

Gambar 14Halaman Hasil Konsultasi 


\section{Kesimpulan}

Kesimpulan dan saran pada penelitian ini adalah sebagai berikut.

Dalam merancang dan membangun website ini menggunakan metodologi pengembangan perangkat lunak Waterfall Menurut Summerville tahun 2011

Pada Sistem Pakar ini hanya bisa untuk mendiagnosa kerusakan hardware laptop. Pada Sistem Pakar ini menggunakan Metode Forward Chaining sebagai mesin inferensi yang melakukan penelusuran gejala-gejala ke depan berdsarkan fakta-fakta yang ada. Pada studi kasus ini penelusuran gejala dalam metode fordward chaining minimal sebanyak 2 gejala dan maksimal sebanyak 6 gejala.

Metode Dempster Shafer sebagai proses penarikan kesimpulan yang menghitung kombinasi nilai belief (nilai densitas baru) karena itu minimal 2 gejala yang di inputkan, di hitung terlebih dahulu nilai Plausiblity-nya lalu menghitung kombinasi nilai belief dari gejalagejala dimana nilai densitas terbaru yang terbesar akan diambil sebagai hasil diagnosa kerusakan laptop. Pada website sistem pakar ini pengunjung melakukan konsultasi dengan menjawab pertanyaan yang tersedia selanjutnya mendapakan hasil dan juga mendapakan info perawatan laptop.

\section{Daftar Pustaka}

[1] Budiharto, Widodo dan Darwin Suhartono. 2014. Artificial Intelligence Konsep dan Penerapannya. Yogyakarta : ANDi

[2] Effendi,Ilham.2014. Apa Pengertian Dari Laptop dan Fungsinya?(online:https://www.itjurnal.com/apa-pengertian-dari-laptop-dan-fungsinya/, diakses 16 April 2018)

[3] Kadir, Abdul. 2005. Dasar Pemrograman WEB Dinamis Menggunakan PHP. Yogyakarta : ANDI.

[4] Kusrini. 2008. Aplikasi Sistem Pakar. Yogyakarta : ANDI.

[5] Kusumadewi, Sri. 2003. Artificial Intelligence (Teknik dan Aplikasinya). Yogyakarta : Graha Ilmu.

[6] Komputer, Wahana 2011. Langkah Mudah Troubleshooting Komputer. Yogyakarta : ANDI

[7] Malik, Maulana. 2016. Sistem Penalaran Berbasis Kasus Untuk Mendiagnosa Kerusakan Pada Komputer. Kendari : Universitas Halu Oleo.

[8] Pramudia, Haris, dan Adi Nugroho. 2017. Sistem Informasi Kerusakan Laptop Menggunakan Metode Naive Bayes. Salatiga : Universitas Satya Wacana. 